УДК 346.548:614.27

DOI https://doi.org/10.32849/2663-5313/2020.8.12

\title{
Іван Демченко,
}

канд. юрид. наук,

викладач кафедри судової медичини та медичного права

Начіонального медичного університету імені О. О. Богомольия

\section{ДОГОВОРИ КЕРОВАНОГО ДОСТУПУ: ЗАГАЛЬНА ХАРАКТЕРИСТИКА}

У даній статті досліджуються нові положення Основ законодавства Украйни про охорону здоров'я щодо договорів керованого доступу. Надається загальний огляд договорів керованого доступу у європейській практииі: фінансових договорів та договорів на основі результатів. Відзначається, що договори керованого доступу - це різні варіації інструментів, механізмів, які спрямовані на забезпечення доступу до лікарських засобів, що може набувати різні форми. Зазвичай - у формі договору між виробником (дистриб'ютором) та замовником (можуть бути різні суб'єкти). Аналізуються положення статті 79-1 Основ законодавства України про охорону здоров'я щодо сторін, предмета, змісту договорів керованого доступу. Сторонами є Міністерство охорони здоров'я України та/або закупівельна організачія та заявник та/або власник реєстрачійного посвідчення на оригінальний (інноваиійний) лікарський засіб. Договір керованого доступу не може бути укладений з компанією, яка не представлена на фармачевтичному ринку Украйни. Звертається увага на проблеми у визначенні предмета договорів керованого доступу - оригінального (інновачійного) лікарського засобу з точки зору вимог щодо його державної реєстрачії та аспектів прав інтелектуальної власності. Підтримується позииія щодо закріплення на законодавчому рівні визначення «оригінальний (інноваиійний) лікарський засіб». Предметом договорів керованого доступу можуть бути як лікарські засоби, які включені до програми медичних гарантій, так і ті, які підлягають реімбурсаиії. Зміст договорів керованого доступу становлять положення про кількість лікарських засобів; умови щодо цін на лікарські засоби; джерела фінансування придбання лікарських засобів; порядок розірвання (у тому числі особливі підстави для дострокового розірвання договорів керованого доступу); строк дії договору. Характерною особливістю є питання прозорості інформаиії про договори керованого доступу. Інформація про кількість та ціну на лікарські засоби є ключовою. У публічному доступі такої інформації не буде, оскільки сторони визначають таку інформачію конфіденційною. Підсумовується, що в Україні закріплено фінансовий договір керованого доступу на основі знижки (иіна лікарського засобу), проте положення чинного законодавства прямо не забороняють використання й інших видів договорів.

Ключові слова: доступність лікарських засобів, оригінальні лікарські засоби, договори керованого доступу, забезпечення лікарськими засобами, інновації.

Постановка проблеми. 3 початку 2020 року темою номер один в Україні та світі $\epsilon$ глобальна пандемія Covid-19. 3 метою підвищення ефективності та упорядкування відносин у сфері захисту від інфекційних захворювань до національного законодавства було внесено та вноситься багато змін. До цих змін прикута увага науковців, фахівців, що займаються закупівлею медичної продукції, та громадськості. Разом із тим 17 березня 2020 року Верховною Радою України був прийнятий Закон України «Про внесення змін до деяких законів України, спрямованих на підвищення доступності лікарських засобів, медичних виробів та допоміжних засобів до них, які закуповуються особою, уповноваженою на здійснення закупівель у сфері охорони здоров'я» № 531-IX [1] (далі - Закон України № 531-IX), яким, 3-поміж іншого, було закріплено положення про договори керованого доступу. Договори керованого доступу (далі - ДКД) - це новий для вітчизняного законодавства інструмент, спрямований на підвищення доступності лікарських засобів (а також медичних виробів та допоміжних засобів до них, проте з метою спрощення тексту, будемо вказувати лише лікарські засоби).

Аналіз останніх досліджень і публікацій. Хоча ДКД і є новим явищем для правової науки в Україні, все ж таки слід відзначити роботи вітчизняних науковців, які у своїх роботах згадували про ДКд; це, зокрема, С.Б. Булеца [2] [3], О. М. Заліська, Х.-О.Я. Стасів [4]. ДКД розглядались переважно у роботах іноземних науковців, серед яких варто відзначити праці А. Ферраріо та П. Канавоса [5], М. Клемпа, К. Фронсдала, К. Фейсі [6] та інших. Загалом, окремих досліджень, присвячених ДКД, в Україні 
майже не проводилось, і тому дана публікація має на меті провести таке дослідження.

Мета даної статті - надати загальну характеристику ДКД за законодавством України. Задля досягнення поставленої мети вбачаємо необхідним вирішити такі завдання: розглянути основи застосування ДКД у країнах Європи, дослідити положення статті 79-1 Основ, визначити сторони, предмет та зміст ДКД за законодав॥ ством України.

Виклад основного матеріалу. ДКД доволі поширений інструмент у країнах Європи. При цьому підхід та розуміння ДКД може відрізнятися у різних країнах У зарубіжних дослідженнях пропонуються різні підходи до визначення ДКД. Зокрема ДКД - це угода між виробником та платником/постачальником, яка забезпечує доступ до (охоплення/відшкодування) медичних технологій за певних умов. Такі угоди можуть мати різноманітні механізми щодо визначення продуктивності технологій або управління технологіями з метою збільшення ефективності їх використання зі зменшенням навантаження на бюджет. [6, р. 79]. Договори керованого доступу - це набір інструментів, спрямований на забезпечення доступу до нових лікарських засобів [7, p. 1271].

Виділяють два види ДКД:

1. Фінансові договори (financial based). Угоди між виробником та платником, основані на досліджуваних фінансових показниках [8] або спрямовані на управління впливом на бюджет, що пов'язаний з впровадженням нових технологій [9].

У свою чергу, виділяють фінансові ДКД, спрямовані на забезпечення інтересів пацієнта або населення. До першої (інтереси пацієнта) категорії належать фінансові ДКД, спрямовані на: обмеження витрат (тобто визначена максимальна сукупна вартість лікування на одного пацієнта (протягом певного періоду часу), і поза цим порогом фармацевтичний виробник надає свій препарат зі знижкою або безкоштовно); обмеження використання (тобто загальна кількість доз або циклів лікування узгоджена. Будь-яке перевищення цієї межі карається штрафом); безкоштовне або знижене лікування (тобто терапія безкоштовна або знижена до визначеної кількості доз або циклів лікування). До другої (інтереси населення) категорії належать наступні фінансові ДКД: «знижки» (тобто фармацевтичний виробник надає знижку для Національної служби охорони здоров'я для всіх пацієнтів або для окремої групи пацієнтів, наприклад для осіб, які живуть з ВІЛ/ СНІД) та угоди «ціна-обсяг», які можуть бути обмеженими або необмеженими. В угоді «ціна-обсяг» 3 обмеженнями встановлюється певний обсяг (зазвичай обраховується як прогнозований), який має бути закуплений. Якщо умови договору виконані, зазначена (прогнозована) кількість лікарського засобу закуплена або перевищена - фармацевтичний виробник надає знижку. В угоді «цінаобсяг» без обмежень ціна лікарського засобу напряму залежить від обсягу поставленого лікарського засобу: чим більший обсяг - тим менша ціна. Це лише декілька можливих варіацій фінансових ДКД.

2. Договори на основі результатів (outcome based). Угоди, основані на визначених результатах (зазвичай клінічних), або угоди, основані на дослідженні нових показань. Наприклад, ДКД, ціна яких обраховується виходячи з результатів конкретного пацієнта та можливості відшкодування такого лікування. ДКД на основі результатів потребують значного розвитку оцінки медичних технологій (Health technology assessment).

ДКД у законодавстві України. Питанню ДКД в Україні присвячена окрема стаття 79-1 Основ законодавства України про охорону здоров'я (далі - Основи) [10]. Проаналізуємо положення даної статті:

Сторони ДКд. Згідно з частиною 1 статті 79-1 Основ сторонами ДКД є:

(I) Міністерство охорони здоров'я України (далі - МОЗ України) або особа, уповноважена на здійснення закупівель у сфері охорони здоров'я (далі - Закупівельна організація). Натепер такою організацією $€$ Державне підприємство «Медичні закупівлі України». При цьому МОЗ України може бути ініціатором, а Закупівельна організація має діяти за дорученням МОЗ України. Цілком логічно, що стороною ДКД $€$ центральний орган виконавчої влади, який є головним розпорядником бюджетних коштів [11]. Однак у самому визначенні ч. 1 ст. 79-1 Основ йдеться про таке джерело фінансування, як кошти місцевих бюджетів, що видається не зовсім логічним: як МО3 України (чи Закупівельна організація) зможе оперувати коштами місцевого бюджету, якщо розпорядниками коштів місцевих бюджетів є місцеві державні адміністрації, виконавчі органи та апарати місцевих рад (секретаріат Київської міської ради), головні управління, управління, відділи та інші самостійні структурні підрозділи місцевих державних адміністрацій, виконавчих органів місцевих рад в особі їх керівників (ч. 2, ст. 22) [12].

(II) Заявник, яким є власник реєстраційного посвідчення на оригінальний (інно- 
ваційний) лікарський засіб (оригінальний біологічний лікарський засіб) або уповноважений ним представник. Фактично це є фармацевтична компанія, яка здійснює виробництво та/або має патент на інноваційний лікарський засіб. Тобто МОЗ України не може укладати ДКД з компанією, яка фактично не представлена на вітчизняному фармацевтичному ринку. Іноземній компанії, яка здійснюе виробництво інноваційного лікарського засобу, щоб укласти ДКД, потрібно пройти процедуру державної реєстрації лікарського засобу в Україні.

Предмет ДКД. Предметом ДКД є постачання оригінального (інноваційного) лікарського засобу (ч. 1, ст. 79-1) [10]. Оригінальний (інноваційний) лікарський засіб - це лікарський засіб, що був уперше у світі зареєстрований на основі повного комплекту документів щодо його якості, безпеки та ефективності (повної реєстраційної інформації) (п. п. 36, п. 1, р. II) [13]. Дане визначення порушує два ключові проблемні аспекти.

Аспект, визначений у процедурі державної реєстрації: предметом ДКД може бути лише оригінальний (інноваційний) лікарський засіб, що, за вищенаведеним визначенням, є таким лікарським засобом, який уперше у світі зареєстрований на основі повної реєстраційної інформації, при цьому такий лікарський засіб має бути зареєстрований в Україні.

Слід зважати, що відповідно до положень ст. 9 Закону України «Про лікарські засоби» [14] в Україні державну реєстрацію лікарського засобу можливо здійснити за повним досьє (автономним досьє) (повна процедура) або за спрощеною процедурою. Спрощена процедура можлива для: (1) лікарських засобів, зареєстрованих компетентними органами Сполучених Штатів Америки, Швейцарії, Японії, Австралії, Канади або зареєстрованих за централізованою процедурою компетентним органом Європейського Союзу; (2) лікарських засобів, які закуповуються спеціалізованими закупівельними організаціями; (3) для лікування соціально небезпечних хвороб (туберкульоз, ВІЛ/ СНІД, вірусні гепатити), рідкісних (орфанних) та онкологічних захворювань. Спрощена процедура не передбачає державну реєстрацію за повною реєстраційною інформацією, проте переважна кількість лікарських засобів, які реєструються в Україні за спрощеною процедурою, $є$ оригінальними (інноваційними) лікарськими засобами.

Аспект інтелектуальної власності: вищенаведене визначення «оригінальний (інноваційний) лікарський засіб» критикується за його неповноту (обмеженість) [15], наго- лошується, що сам термін «інноваційність» означає не лише його першу державну реєстрацію та державну реєстрацію узагалі, а й отримання прав інтелектуальної власності (насамперед, патентного захисту), введення нових речовин, нових показань до застосування, нових методів лікування, що може бути особливо важливим у контексті Covid-19, тощо. Якщо застосувати суто формальний підхід, аспект інтелектуальної власності не впливає на те, чи може бути оригінальний лікарський засіб предметом ДКД. 3 іншого боку, патентний захист є ознакою, що свідчить про новизну, інноваційність, оригінальність лікарського засобу. Тому підтримуємо пропозицію I. Вороніної, яка пропонує закріпити на законодавчому рівні таке визначення: оригінальний (інноваційний) лікарський засіб - лікарський засіб, що був уперше у світі зареєстрований на основі повного реєстраційного досьє (повного комплекту документів щодо його ефективності, безпеки та якості) та має патентний захист активних компонентів на певний період часу [15, с. 52].

Предметом ДКД, як визначено у ч. 5 ст. 79-1 Основ, можуть бути лікарські засоби, які включені до програми медичних гарантій та які підлягають реімбурсації. Нагадаємо, що такі лікарські засоби мають бути: 1) зареєстровані в Україні; 2) використовуватися для лікування медичних станів (захворювань), визначених Кабінетом Міністрів України; 3) бути включеними до Національного переліку основних лікарських засобів, переліку міжнародних непатентованих назв лікарських засобів, Реєстру лікарських засобів, які підлягають реімбурсації [16].

Зміст ДКД. Ч. 2 ст. 79-1 Основ визначає, які положення має містити ДКД. Зокрема, це:

(1) кількість лікарських засобів, які заявник зобов'язується постачати на територію України протягом строку, визначеного договором керованого доступу;

(2) умови щодо ціни на лікарські засоби, за якою заявник зобов'язується постачати лікарські засоби на територію України протягом строку, визначеного договором керованого доступу;

(3) джерела фінансування придбання лікарських засобів, що є предметом договору керованого доступу;

(4) порядок розірвання договору керованого доступу. До однієї з підстав дострокового розірвання ДКД можна віднести положення ч. 4 ст. 79-1 Основ: у разі державної реєстрації в Україні генеричного лікарського засобу (подібного до біологічного лікарського засобу) із такою самою міжнародною непатентованою назвою, формою випуску та дозуванням, що і лікарський засіб, щодо 
якого укладено ДКД, ДКД підлягає достроковому розірванню 31 грудня поточного бюджетного року, якщо строк дії такого договору не закінчується раніше зазначеної дати. Укладення, виконання, зміна та припинення ДКД здійснюються відповідно до положень законодавства України. Звертаємо увагу на положення чинного законодавства щодо визначення генеричного лікарського засобу. Так, генеричний лікарський засіб - лікарський засіб такого самого якісного і кількісного складу діючих речовин і такої самої лікарської форми, як і референтний лікарський засіб, біоеквівалентність якого з референтним лікарським засобом було продемонстровано належними дослідженнями біодоступності. Різні лікарські форми для перорального застосування 3 негайним вивільненням вважатимуться однією і тією самою лікарською формою. Дослідження біодоступності не вимагатимуться від заявника, якщо він доведе відповідність генеричного лікарського засобу встановленим критеріям, визначеним у відповідних детальних настановах [13]. Положення Основ встановлюють більш жорсткі вимоги до генеричних лікарських засобів, державна реєстрація яких в Україні може бути підставою для дострокового розірвання ДКД.

Договір керованого доступу може містити інші умови та зобов'язання сторін, що не суперечать законодавству.

Порядок проведення переговорів щодо договорів керованого доступу, види таких договорів та порядок їх укладення, виконання, зміни та припинення, а також типова форма такого договору затверджуються Кабінетом Міністрів України [10, ч. 4, ст. 79-1]. Натепер підзаконні нормативноправові акти, які б розкривали ці питання, не затверджені. Відповідно до Закону України № 531-IX, Кабінет Міністрів України має протягом 6-ти місяців з моменту набрання чинності (18 березня 2020 року) цим законом: (1) розробити та затвердити постанову Кабінету Міністрів України, якою встановити порядок проведення переговорів щодо договорів керованого доступу, види таких договорів та порядок їх укладення, виконання, зміни та припинення; (2) привести свої нормативно-правові акти у відповідність до цього Закону у частині забезпечення функціонування договорів керованого доступу; (3) забезпечити перегляд та приведення міністерствами та іншими центральними органами виконавчої влади їх нормативно-правових актів у відповідність до цього Закону в частині забезпечення функціонування договорів керованого доступу. Фактично Кабінет Міністрів України має термін до 18 вересня 2020 року для розроблення відповідних нормативно-правових актів та приведення у відповідність чинних.

Відзначаємо, що стосовно видів ДКД, які зазначені вище, в Україні йдеться про фінансовий ДКД на основі знижки. Хоча зазначені положення ч. 4 ст. 79-1 Основ дають можливість припустити, що можливі й інші види договорів.

Звертаємо увагу, що у статті використовується термін «переговори», який є не розкритим у чинному законодавстві України. Зазвичай цей термін використовується в аспекті домовленостей, які передують укладанню правочинів [17, с. 16].

Інформація з обмеженим доступом. Сторони договору керованого доступу можуть визначити окремі положення ДКД інформацією з обмеженим доступом [10, ч. 6 ст. 79-1]. Однак, відповідно до ч. 7 ст. 79-1 Основ, MO3 України розміщуе на своєму офіційному веб-сайті інформацію про міжнародну непатентовану назву, торговельну назву, форму випуску та дозування лікарського засобу, щодо якого укладено договір керованого доступу, назву заявника, інформацію про уповноваженого представника заявника (за наявності), строк дії договору керованого доступу. Будь-які положення щодо транспарентності діяльності державних органів є значним досягненням і повинні всіляко вітатися.

Питання доступу до інформації щодо умов ДКД є актуальним і для інших країн. Так, у Франції, Бельгії, Чехії умови ДКд є суворо конфіденційними. В Італії, Великобританії, Уельсі, Шотландії та Швеції є публічною інформацією, за винятком ціни на лікарські засоби [18]. Саме інформація про кількість та ціну на лікарські засоби $€$ ключовою. На сайті ж МОЗ України такої інформації не буде, та, вірогідно, сторони визначать інформацію про кількість та ціни конфіденційною.

Істотною умовою договору, з-поміж іншого, є умова щодо строку дії договору. У європейській практиці застосовуються ДКД строком до 5 років (переважно 2-3 роки) 3 можливістю їх перегляду за певних умов (зміна ціни, допуск на ринок нових препаратів тощо). Залежить строк дії ДКД від класу інноваційного препарату, обсягу закупівель та законодавчих вимог кожної країни [3, с. 288]. Мабуть, в Україні ДКД також буде укладатись на такі самі терміни.

Наостанок спробуємо визначити можливі перспективи ДКД в Україні. Для цього слід звернути увагу на наявний досвід застосування ДКД у європейських країнах. Інформація щодо ДКД часто є конфіденційною інформацією, і тому будь-які дослідження 
базуватимуться на неповній інформації. Наприклад, у дослідженні 2017 року [18] проводився аналіз ДКД у 8 країнах, що входять до Свропейського Союзу (далі - СС), стосовно лікарських засобів для лікування онкологічних захворювань, третина 3 них була орфанними лікарськими засобами. Ми: 1) взяли за основу інформацію щодо лікарських засобів, які були названі у наведеному дослідженні; 2) перевірили інформацію з Єдиного державного реєстру лікарських засобів України (щодо того, чи зареєстровані такі лікарські засоби в Україні); 3) подивились відомості з Державного реєстру свідоцтв України на знаки для товарів і послуг (щодо того, чи мають такі лікарські засоби патентний захист). Результати цього дослідження $є$ такими.

Bevacizumab (міжнародна непатентована назва, надалі - МНН) - лікарський препарат 3 найбільшою кількістю ДКД, а саме - 10 ДКД у трьох різних країнах за 6-ма різними показаннями для застосування. В Україні Bevacizumab зареєстрований під торговою маркою АВАСТИН®. Заявником виступає компанія Ф. Хоффманн-Ля Рош Лтд, Швейцарія.

Enzalutamide (MHH) та aberitaterone acetate (MHН) - ДКД для цих препаратів, які застосовуються у лікуванні раку простати, наявні у шести з восьми досліджуваних країн.

Enzalutamide в Україні зареєстрований під торговою маркою Кстанді® (свідоцтво на знак для товарів та послуг від 25.06.2020), заявником виступає компанія Астеллас Фарма Юроп Б.В., Нідерланди. Aberitaterone acetate в Україні зареєстрований під торговою маркою Зитига ${ }^{\circledR}$ (свідоцтво на знак для товарів та послуг від 25.05.2012. Діє до 30 червня 2021 року)

Вищезазначені три препарати мають потенційну можливість стати предметом ДКД в Україні. Формування більш точного переліку, проведення переговорів має розпочати безпосередньо Міністерство охорони здоров'я України (або за дорученням МО3 - ДП «Медичні закупівлі України») вже у 2020 році для того, аби укласти перші ДКД на 2021 рік.

\section{Висновки}

Підсумовуючи наведене вище, враховуючи зазначені положення національного законодавства, певним чином спростимо визначення ДКД. Отже, договір керованого доступу - це договір, що укладається між Міністерством охорони здоров'я України (Закупівельною організацією) та фармацевтичною компанією (iї представником) щодо постачання оригінального (інноваційного) лікарського засобу на територію України за кошти державного бюджету та/або місцевих бюджетів з метою забезпечення доступності таких лікарських засобів для пацієнтів.

Особливостями ДКД є:

- визначені сторони ДКД; особливий предмет;

- визначене джерело оплати / коштів;

- особливий порядок укладання, виконання, зміни та припинення;

- положення щодо доступності інформації про ДКД.

ДКД - один із можливих способів забезпечення доступності насамперед нових, оригінальних (інноваційних, захищених патентами) лікарських засобів.

При цьому ДКД для трьох основних заінтересованих осіб матиме різні переваги та недоліки.

Для держави (в особі Міністерства охорони здоров'я України) - це можливість забезпечити доступність оригінальних (інноваційних) лікарських засобів для населення; потенційно - заощадити кошти державного бюджету.

Для фармацевтичних компаній укласти вигідні угоди для гарантованого доступу своїх препаратів на фармацевтичних ринок України.

Для пацієнтів - отримати оригінальні лікарські засоби у рамках програми медичних гарантій чи інших спеціалізованих програм.

ДКД можуть стати інструментом, який збалансує зазначені інтереси.

\section{Список використаних джерел:}

1. Про внесення змін до деяких законів України, спрямованих на підвищення доступності лікарських засобів, медичних виробів та допоміжних засобів до них, які закуповуються особою, уповноваженою на здійснення закупівель у сфері охорони здоров’я : Закон України № 531-IX від 17 березня 2020 року. Відомості Верховної Ради України. 2020. №. 26. С. 30. Ст. 956.

2. Булеца С. Б. Особливості договору керованого доступу в умовах COVID-19. Проблеми правового регулювання иивільних відносин в умовax COVID-19 : матеріали Всеукраїнської науково-практичної онлайн конференції 23 квітня 2020 року. Одеса : Фенікс, 2020. С. 12-19.

3. Булеца С. Б. Договір керованого доступу в умовах пандемії: переваги та недоліки. Права приватної особи в умовах пандемії COVID-19: проблеми здійснення та захисту / за ред. Є. О. Харитонов, О. І. Харитонова, К. І. Бєляков. Одеса: Видавничий дім «Гельветика», 2020.

4. Заліська О. М., Стасів Х.-О. Я. Науковометодичне обгрунтування та використання методології «Угоди керованого доступу» для інно- 
ваційних лікарських засобів у системі оцінки медичних технологій в Україні. Фармацевтичний журнал. 2019. №. 4. С. 32-40

5. Ferrario A., Kanavos P. Managed entry agreements for pharmaceuticals: the European experience. Brussels, 2013.

6. Klemp M., Frønsdal K. B., Facey K. What principles should govern the use of managed entry agreements? International Journal of Technology Assessment in Health Care. 2011. Vol. 27. No. 1. P. 77-83.

7. The Implementation of Managed Entry Agreements in Central and Eastern Europe Findings and Implications / Ferrario A., Arāja D. Bochenek T. та ін. PharmacoEconomics. 2017. Vol. 35. No. 12. P. 1271-1285.

8. Bouvy J. C., Sapede C., Garner S. Managed entry agreements for pharmaceuticals in the context of adaptive pathways in Europe. Frontiers in Pharmacology. 2018. Vol. 9.

9. Reconciling uncertainty of costs and outcomes with the need for access to orphan medicinal products: A comparative study of managed entry agreements across seven European countries Morel T., Arickx F., Befrits G. та ін. OrphanetJournal of Rare Diseases. 2013. Vol. 8. No. 1.

10. Основи законодавства України про охорону здоров'я : Закон України від 19 листопада 1992 № 2801-XII (із змінами). Відомості Верховної Ради України. 1993. № 4. С. 19.

11. Порядок використання коштів, передбачених у державному бюджеті для виконання програм та здійснення централізованих заходів 3 охорони здоров'я : затверджений Постановою Кабінету Міністрів України № 298 від 17 березня 2011 року (у редакції Постанови Кабінету
Міністрів № 1172 від 27 листопада 2019 року) (зі змінами). Офімійний вісник Украӥни. 2011. № 22. С. 56. Ст. 917.

12. Бюджетний кодекс України : Закон України № 2456-VI від 08 липня 2010 року (зі змінами). Офіиійний вісник Украӥни. 2010. № 59. С. 9.

13. Порядок проведення експертизи реєстраційних матеріалів на лікарські засоби, що подаються на державну реєстрацію (перереєстрацію), а також експертизи матеріалів про внесення змін до реєстраційних матеріалів протягом дії реєстраційного посвідчення : затверджено Наказом Міністерства охорони здоров’я України № 426 від 26 липня 2005 року (у редакції наказу Міністерства охорони здоров’я України № 460 від 23 липня 2015 року) (зі змінами). Офічійний вісник України. 2005. № 39. С. 107. Ст. 2494.

14. Про лікарські засоби : Закон України № 123/96 від 04 квітня 1996 року (зф змінами). Відомості Верховної Ради України. 1996. № 22. С. 86.

15. Вороніна I. С. Правова характеристика інноваційних лікарських засобів. Право та інноваuiï. 2015. № 2 (10). С. 49-54.

16. Порядок реімбурсації лікарських засобів : затверджено Постановою Кабінету Міністрів України № 152 від 17 березня 2017 року (у редакції постанови Кабінету Міністрів України № 135 від 27 лютого 2019 року) (зі змінами). Офiиійний вісник Украӥни. 2017. № 26. С. 75. Ст. 749..

17. Кармаза О. Медіація та переговори як альтернативні способи вирішення спорів. Підприємництво, господарство і право. 2020. № 5. С. 13-18.

18. Managed Entry Agreements for Oncology Drugs: Lessons from the European Experience to Inform the Future / Pauwels K., Huys I., Vogler S. та ін. Frontiers in Pharmacology. 2017. Vol. 8.

\section{Ivan Demchenko. Managed entry agreements: general characteristics}

This article examines the new provisions of the Fundamentals of the legislation of Ukraine on health care for managed entry agreements. An overview of managed entry agreements in European practice is provided: financial agreements and performance-based agreements. It is noted that managed entry agreements combine from different variations of tools, mechanisms aimed to provide access to medicines. Usually, it's an agreement between the manufacturer (distributor) and the customer (there may be different subjects). The provisions of Article 79-1 of the Fundamentals of the legislation of Ukraine on health care regarding the parties, subject matter, content of managed entry agreements are analyzed. The parties are the Ministry of Health of Ukraine and / or the purchasing organization and the applicant and / or the holder of the registration certificate for the original (innovative) medicinal product. A managed entry agreement cannot be concluded with a company that is not represented on the pharmaceutical market of Ukraine. Attention is drazen to the problems in determining the subject of controlled access agreements - the original (innovative) medicinal product in terms of requirements for its state registration and aspects of intellectual property rights. The position on consolidating the definition of an original (innovative) medicinal product at the legislative level is supported. The subject of managed entry agreement can be both medicines that are included in the medical guarantee program and those that are subject to reimbursement. The content of managed entry agreement are provisions on the number of drugs; conditions regarding medicines prices; sources of financing for purchase of medicines; termination procedure (including special grounds for early termination of managed access agreements, like registration of generic medicine with the same substance); term of the agreement. A characteristic feature is the issue of information transparency of managed entry agreements. Information on the quantity and price of medicines is essential and most valuable. Such information will not be publicly available, as the parties will define such information as confidential. It is concluded that Ukraine has a financial agreement of managed entry on the basis of a discount (the price of the drug), but the provisions of current legislation do not explicitly prohibit the use of other types of agreements.

Key words: availability of medicines, original medicines, managed entry agreements, purchase of medicines, innovation. 